\title{
7 OST-WAR FRIENDSHIP BETWEEN NEIGHBORS: AN OUTLINE OF SOVIET-FINNISH MUSIC EXCHANGES FROM 1944 TOWARDS THE COLLAPSE OF THE SOVIET UNION
}

\section{Meri Elisabet Herrala}

University of Helsinki, E-mail: meri.herrala@helsinki.fi

\section{Acknowledgements}

This paper is based on the presentation made at the Fifth international conference on Baltic and Nordic Studies in Romania A piece of culture, a culture of peace, re-imaging European communities in the North Sea, Baltic Sea and Black Sea regions, hosted by Valahia University of Târgovişte and the Romanian Association for Baltic and Nordic Studies, August 17-19, 2014. Supported by EEA Grants, contract no 4/22.07.2014.

\begin{abstract}
:
In this article, I will analyze the role of music in the process of building peaceful relations between the Soviet Union and the Republic of Finland after the Second World War. The role of music as a weapon of "soft power" was an important alternative in Finnish-Soviet relations in order to enhance understanding between them and to avoid further conflict.

I will analyze how the leading Soviet soloists were often first "tested" in Finland before their further outreach to the West from 1944 to the collapse of the Soviet Union. Because of its position as a neutral country between the East and the West Finland was seen as a safe experimental location in which to evaluate the performers' loyalties to the Soviet regime. However, violinist Victoria Mullova's 1983 defection to the West via Finland showed that the Soviet power was not so overpowering any more, even towards its own citizens. The Soviet Union was already heading for a collapse due to political and economic realities. Its diminishing cultural influence on the West undermined its power, and accelerated its demise.

Using primary source materials and newspapers mainly from the Finnish National Archives and Sibelius Museum as well as the former Soviet archives in Moscow, I will examine the ways in which Soviet government cooperated with Finnish non-governmental organizations such as the Finland-Soviet Union Friendship Society, the main coordinating body of Finnish-Soviet relations, Finnish concert firms etc.
\end{abstract}

\section{Rezumat:}

In acest articol voi analiza rolul muzicii în procesul construirii relațiilor pașnice între Uniunea Sovietică şi Republica Finlanda, după două războaie devastatoare - Războiul de Iarnă și Războiul de Continuare. Rolul muzicii ca armă a "puterii soft"a fost o alternativă importantă în relațiile finlandezo-sovietice, urmărind consolidare ințelegerii dintre cele două părți și evitarea viitoarelor conflicte. Voi arăta modul în care soliștii erau adesea "testați" 
mai întâi în Finlanda, înainte de a porni spre Vest. Datorită poziției sale de stat neutru între Răsărit și Apus, Finlanda era văzută ca un loc sigur pentru experimente, în care putea fi evaluată loialitatea interpreților față de regimul sovietic. Cu toate acestea, cererea de azil politic adresată Occidentului de către violonista Victoria Mullova în 1983 din Finlanda a arătat faptul că puterea sovietică nu mai era atât de covârşitoare, chiar față de propriii cetățeni. Odată cu declinul influenței culturale sovietice în Occident, sistemul sovietic însuși se îndrepta spre sfârşit. Voi examina, de asemenea, modul în care guvernul sovietic a cooperat cu organizațiile non-guvernamentale finlandeze, precum Societatea FinlandezoSovietică, principalul organism de coordonare a relațiilor dintre cele două state, cu firmele finlandeze de concerte etc.

Keywords: "soft-power" diplomacy, the Finland-Soviet Union Friendship Society, the Finnish-Soviet Agreement of Friendship, Cooperation and Mutual Assistance, Emil Gilels, David Oistrakh, Sviatoslav Richter, Mstislav Rostropovich, Vladimir Ashkenazy, Victoria Mullova

After the two devastating wars between Finland and the Soviet Union deteriorating relations between them ${ }^{1}$ some means of reconciliation - or at least peaceful coexistence - became necessary. Culture (together with economic and scientific relations) filled that role, becoming a medium that offered peaceful means for furthering understanding between the two countries.

From 1945 onwards, the Soviet artists, dance groups, writers, composers, musicians, art exhibitions, and cosmonauts visited Finland, showcasing the products of the great socialist experiment. A similar type of outreach was directed from Finland to the Soviet Union.

In this article, I will analyze how Soviet classical musicians, especially David Oistrakh, Emil Gilels, Sviatoslav Richter, Mstislav Rostropovich, Vladimir Ashkenazy, and Viktoria Mullova were used as cultural diplomats in relations between the Soviet Union and Finland. My case studies are selected not only because of their underlying force of diplomacy, but also because of their value and importance in showing the transition and subsequent expansion of the Soviet artistic diplomatic initiative from East to West, many times, via Finland. Soviet artists who were sent on foreign concert tours were selected using the criteria of their impact on foreign audiences. Therefore, the Soviets attached their highest hopes to their top performers.

I will concentrate on Soviet outreach to Finland than vice versa. I will mainly provide a general historical perspective of music exchanges between the Soviet Union and the Republic of Finland concentrating primarily on the Soviet Union

\footnotetext{
1 According to Soviet terminology, the war between the Soviet Union and Finland was called the Great Patriotic War. The so-called Winter War broke out between Finland and the Soviet Union on November 30, 1939 when the Soviet Union attacked Finland. The war ended on March 13, 1940. The Continuation War (a Finnish term) started when Germany, as a part of Eastern Front activities, started its invasion of the Soviet Union. Open warfare started with the Soviet air offensive to Finland on June 25, 1941. The war ended with the Moscow Armistice on September 19, 1944 and Paris Peace Treaty concluded the war formally in 1947.
} 
sending their soloists to Finland while touching on some aspects of transnational cultural exchanges between them. ${ }^{2}$

I suggest that music, as a tool of "soft power," to affect others through attraction rather than coercion, was an important alternative in the quest to maintain friendly relations between Finland and the Soviet Union. "Soft power" was a means to exchange information about each other's systems and culture thus strengthening cultural and ideological influences. ${ }^{3}$

After the Soviet Union emerged from the isolation of 1930s and 1940s, its first steps were to construct and solidify a cultural sphere of influence within its bloc of occupied countries. As a result of the Soviet victory in World War II, cultural exchange became an important means for the attainment of Soviet foreign policy goals. With this accomplished, the Soviets took the next step of gradually reaching out to the Western World. This emergence onto a larger stage triggered an unprecedented period of outreach and cooperation between the USSR and Finland. In the Soviet policies of culture and its cultural exchange Finland was a special case between the East and the West.

From the Finnish perspective, cordial relations with the Soviet regime were a necessity based on economic and military self-preservation, but for the Soviet Union, the stakes were different. With its cultural outreach, the process of "Communist take-over," and the establishment of the Soviet sphere of interest in the Central East European countries, the Soviet Union strove to strengthen Soviet cultural and ideological influences, advertise its successes, and promote a picture of superiority of its system in the eyes of its counterparts and cultural exchange partners such as Finland.

Finland's position within the Soviet cultural sphere that was in the process of forming after the Second World War was unique. Finland was never integrated into the Soviet bloc, or into the Soviet cultural sphere as were the Central East European countries. Therefore, Finland never conformed to Soviet style political, social and cultural policies. Due to the fact that the coup attempt failed in Finland in 1948, Soviet style institutions, customs and cultural policies never adapted in Finland as they were in Central East European countries with their communist

\footnotetext{
2 Transnational cultural contacts involve the cross-border exchanges of non- and sub-state actors below the level of the official government diplomacy - the movement of groups, goods, technology, ideas, culture or people such as Soviet classical musicians across national borders. Clavin, Patricia, "Defining Transnationalism," Contemporary European History, 144 (2005), 421-439. David-Fox, Michael, "Transnational History and the East-West Divide" in Peteri, György, Imagining the West in Eastern Europe and the Soviet Union (University of Pittsburg press 2010); Keohane Robert, and Nye, Joseph S. Jr. (Eds.), Transnational relations and world politics (Cambridge MA: Harward University Press, 1971), IX; See also, Autio-Sarasmo, Sari, Miklóssy, Katalin and Humphreys, Brendan (Ed.), Winter Kept Us Warm: Cold War Interactions Reconsidered (Aleksanteri Cold War Series 1/201)0.

3 See Joseph S. Nye, Jr., Soft Power. The Means to Succeed in World Politics (New York: Public Affairs, 1986); Joseph S. Nye, Jr. "Public Diplomacy and Soft Power", The Annals of the American Academy of Political and Social Science 616: 94 March 2008: 95.
} 
regimes during the period of 1944-1953.4 Therefore the Soviet Union sought to use Soviet musicians as weapon of "soft power" in order to achieve Soviet foreign policy goals by attraction rather than coercion, in Finnish case, in an attempt to integrate Finland into its sphere of influence. ${ }^{5}$

After the Winter and the Continuation Wars, there were wide circles in Finland that were openly favorable to the Soviet Union and its cultural influences. This also has much to do with the fact that Finland had a strong tradition of left-wing parties, and its Communist Party, which had operated undercover in the Soviet Union until 1944, had now returned to the political playing field. The interest in the Soviet Union was also strong in the circles leaning towards the West. Therefore, there was political consensus on the importance of economic and cultural relations with the USSR, on the process of building peaceful relations, and on enhancing mutual understanding in order to avoid further conflicts. This understanding was firmly based on the predominant doctrine - known as the "Paasikivi's Line" which Paasikivi (1946-1956) had developed on the basis of his "realpolitik" type of thinking about Finnish-Soviet relations. This line was further established during the presidency of Urho Kaleva Kekkonen (1956-1982), Paasikivi"s successor, and titled the "Paasikivi-Kekkonen Line. The signing of the treaty between Finland and the Soviet Union (the Friendship, Cooperation and Mutual Assistance Agreement, 1948), also outlined Finnish-Soviet relations and made them special.

According to the interpretation of "Paasikivi-Kekkonen Line", it was understood that the "Soviet Union question" was the number one problem in Finnish politics. Internal and foreign policies of Finland were always closely tied to an awareness of Soviet reaction based on the strategies and policies of the neighboring superpowers. Foreign policy and especially military policy interests of the Soviet Union toward Finland were generally accepted realities. ${ }^{6}$ Thus, Finnish politics towards the Soviet Union has been described with a derogatory term, Finlandization. The period of so-called Finlandization, started with the signing of the armistice agreement on September 1944, and continued well into the future, basically until the collapse of the Soviet system. The high point of

\footnotetext{
4 Contributions on research pertaining the Sovietization of Central East European countries, see Norman Naimark \& Leonid Gibianskii (ed.), The Establishment of Communist Regimes in Eastern Europe 1944-1949 (USA: Westview Press, 1997); T. V. Bolokitina et al., Moskva i vostochnaya Evropa. Stanovlenie politicheskikh rezhimov Sovetskogo tipa 1949-1953. Ocherki istorii (Moskva: Rosspen, 2002). 5 Joseph S. Nye, Jr., Soft Power. The Means to Succeed in World Politics (New York: Public Affairs, 1986); Joseph S. Nye, Jr. "Public Diplomacy and Soft Power", The Annals of the American Academy of Political and Social Science 616: 94 March 2008: 95.

6 A history of Finlandization is written by professor Timo Vihavainen, see Timo Vihavainen, Kansakunta rähmällään. Suomettumisen lyhyt historia (Helsinki: Kustannusosakeyhtiö Otava, 1991) (Nation on its feet. A Brief history of Finlandization), 32. See a discussion about Finlandization from the site Politiikasta.fi; "Mitä on suomettuminen? (What is Finlandization?), "Suomettumisen paluu" (the Return of Finlandization).
} 
Finlandization occurred during the 1970s and lasted until the end of President Kekkonen's term in 1982.7

The unique relationship of Finland and the Soviet Union shares characteristics common to superpowers and their subordinates within their fields of interests the so-called dominant-subordinate relationship. This relationship of disparity can, to a remarkable extent, be applied to the cultural relations between Finland and the Soviet Union. ${ }^{8}$ This is because all smaller states had disparate relationship with their more powerful neighbors. This relationship also makes PaasikiviKekkonen's line more understandable. Despite the negative aspects of the Soviet Union's influence, Finland acquiesced in the interest of self-preservation.

During the entire Soviet period, Finnish political circles exercised moderation towards the Soviet Union (no discussions, articles criticizing its policies, even establishment of governments and presidents favored by the Soviet Union). Until the collapse of the Soviet Union, the Soviet danger was not yet over. The high point of Finlandization occurred during the 1970s and lasted until the end of President Kekkonen's term in 1982. During the presidency of Mauno Koivisto, Finnish leeway in both its internal and external policies became more relaxed.

At the same time, the Soviet Union sought to infiltrate its cultural influences into Finland as widely as possible, and to remove anti-Soviet feelings of the population. This was a reaction to growing exposure to Western and especially American modernization and American way of life (mass culture, consumer goods and rising standards of living) from the beginning of the 1950s. The Soviets started to send their performers to the West as counteractive measures to the positive images of the American system and its culture.

But in order to show its superiority in the West, and especially in the eyes of its adversary, the United States, the Soviet cultural outreach needed to be expanded much farther than to Finland, which, after all, was a small republic between the East and the West. For the Soviet Union, Finland represented a safe arena in which to test the expansion of its influence beyond the Iron Curtain with fewer political risks. This is because Finland did not really belong to either of the two antagonistic blocs that according to Soviet ideology were developing after the brief collaboration of the Soviet Union with the Allied forces against the common enemy, Nazi Germany, and the post-war reconstruction that followed.

There is hardly any academic research on Finnish-Soviet music interactions. ${ }^{9}$ This is because scholarly research on Cold War cultural policies has only recently

\footnotetext{
7 Timo Vihavainen, Kansakunta rähmällään.

8 David B. Abernethy, "Dominant-Subordinate Relationships," Jan F. Triska (ed.) Dominant Power and Subordinate States (Durham 1986), 105-123; Aappo Kähönen, The Soviet Union, Finland and the Cold War. The Finnish Card in Soviet Foreign Policy, 1956-1959 (Helsinki: Suomalaisen Kirjallisuuden Seura, 2006), 25-26.

9 Only such books as Kaisa Kinnunen, Suomi-Neuvostoliitto-Seuran Historia 1944-1974 (The History of Finland-Soviet Union Friendship Society 1944-1974) (Helsinki: Suomi-Venäjäseura, 1998); Ville Pernaa, Tehtävänä Neuvostoliitto. Opetusministeriön Neuvostoliittoinstituutin roolit suomalaisessa politiikassa 1944-1992 (Mission the Soviet Union. The Roles of the Soviet-Union Institute of the Finnish Ministry of Education in Finnish Politics 1944-1992) (Keuruu: Otava, 2002) touch some aspects of Soviet-Finnish
} 
started. Another reason is that references to Soviet foreign policy strategies and their influence on cultural exchanges are usually contained only in archival depositories of limited access. Without committing oneself to a major research project, relevant information is very hard to find for many intriguing questions of Soviet-Finnish musical interaction. For example the reception of Soviet soloists and performance groups by the Finnish audiences is hard to research without conducting large-scale interviews covering the early stages of Soviet-Finnish music relations. Newspaper reviews of concerts offer the only information of the reception from the point of view of the music critic behind the article, and many potential interviewees who were audience members are no longer living.

\section{Organizational background for cultural exchange}

The Finland-Soviet Union Friendship Society was established 1,5 months after the armistice between Finland and the Soviet Union on October 15, 1944, in order to promote friendly terms between Finland and the Soviet Union while offering information about each other's systems and culture and advancing cultural exchanges between them. It was officially believed that cultural exchanges advanced the understanding between two countries and therefore were important for both Finland and Soviet Union in strengthening relations between them.

After the signing of the Friendship, Cooperation and Mutual Assistance Agreement between Finland and the USSR on April 6, 1948,10 the practical operation of cultural relations became the responsibility of the Finland-Soviet Union Friendship Society (Suomi Neuvostoliitto-Seura, SNS).

Despite the establishment of the Soviet Union Institute in Helsinki, a scientific research institute, which had been established to co-ordinate academic research on the Soviet Union and its system, the maintaining of cultural relations was left to the Finland-Soviet Union Friendship Society. ${ }^{11}$ At first, Finland in its cultural exchanges with the Soviet Union operated mainly within the framework of interaction between friendship societies. Eventually a system of more capitalized concert firms, impresarios and record companies began to insinuate further into

music exchange. See also Olli Turtiainen's Master's thesis, Olli Turtiainen, Täältä tullaan Venäjä! Rock Suomen ja Neuvostoliiton Kulttuurisuhteissa (Here we come Russia! Rock Music in Finnish-Soviet Cultural Relations) (Turun Yliopisto: Politiikan tutkimuksen laitos, poliittinen historia, 2012). Also the study of soft-power diplomacy and the research of cultural and musical exchanges between the Soviet Union and its cultural exchange partners, despite some existing contributions, are only in the beginning stages of research. Much more work and primary materials need to be covered in order to fully enlighten the theme. See first contributions to the theme in the framework of a conference in Jyväskylä organized by Simo Mikkonen et al., International Conference "East-West Cultural Exchanges and the Cold War" (Jyväskylä: June 14-16, 2012). See also the latest issue of Valahian Journal of Historical Studies, 20 (2013).

10 "Sopimus ystävyydestä, yhteistyöstä ja avunannosta Suomen tasavallan ja Neuvostotasavaltojen liiton välillä (YYA-Sopimus)." The development of cultural and economic relations between Finland and the Soviet Union were established in the fifth article of this agreement, Kinnunen 1998, 288.

11 Pernaa 2002, from page 20 onwards. See also the division of work between the Finland-Soviet Union Friendship Society and the Soviet Union Institute, Pernaa 2002, 81, 84. 
the field of the cultural relations between the two neighbors. Generally, the cultural exchange between the USSR and Finland operated within the framework of the Agreement on Friendship, Cooperation and Mutual Assistance of 1948.

However, the Finland-Soviet Union Friendship Society and the Soviet Union Institute in Helsinki obeyed instructions from higher governmental organizations. Despite the official responsibility for the leadership of cultural relations between Finland and the USSR by the Finnish Ministry of Foreign Affairs, questions concerning international cultural exchange and its finances belonged to Finnish Ministry of Education from 1948 onwards. The political department of the Finnish Ministry of Foreign Affairs negotiated with the Soviet Embassy in Finland (Helsinki) on arranging cultural exchanges between the two countries.

In the Soviet Union, a vertically governed top-down structure of control and command directed and controlled Soviet cultural relations with foreign countries. However, as my previous research has shown, despite the totalitarian nature of the system overlapping with mutually connected organizations that also competed with each other, and ambiguous rules guiding the operations, the system did not operate as effectively as it could have, and it was far less centralized than it would seem to be implied. ${ }^{12}$

In the beginning of the 1950s, all Soviet concert tours to Finland were organized by VOKS and subsequent organizations. ${ }^{13}$ The All-Union Society for Cultural Relations with Foreign Countries (VOKS) and its successor, the Union of Soviet Societies for Friendship and Cultural Relations with Foreign Countries (SSOD) were created in order to promote international cultural contacts between writers, composers, musicians, cinematographers, artists, scientists, educators, and athletes of the USSR with those of other countries. ${ }^{14}$ Soviet artists performed only on occasions and in venues approved by the Finland-Soviet Union Friendship Society. Subsequently, the Soviet soloists started to perform in music festivals organized by concert agencies of a more commercial nature than the friendship societies. ${ }^{15}$

In 1958, the State Committee for Cultural Ties Abroad (GKKS) was established very close to the Party leadership. The GKKS rather than the Ministry of Culture handled the below-the-surface negotiations concerning cultural agreements with foreign cultural ministries. The negotiations were conducted by the State Committee on Cultural Affairs (GKKS) and not the Soviet Ministry of Foreign Affairs or the Ministry of Culture, The head of the GKKS, Yuri Zhukov, also reported directly to the party's Central Committee, not to the ministries. In 1958, VOKS was replaced by SSOD, which continued its existence until 1992.16 Also The

\footnotetext{
12 Meri Herrala, The Struggle for Control of Soviet Music From 1932 to 1948: Socialist Realism vs. Western Formalism (The Edwin Mellen Press: Lewinston, Queenston, Lampeter 2012).

13 Kinnunen 1998, 286.

14 However, there is no information in the Finnish archives on how Finns operated with these organizations. VOKS was established in 1925.

15 Kinnunen 1998, 286.

16 See Simo Mikkonen, “'Winning Hearts and Minds?' Soviet Music in the Cold War Struggle against the West" in Twentieth Century Music and Politics, ed. P. Fairclough (Farnham: Ashgate,
} 
Soviet Friendship Society with Finland was established on January 13, 1958 around the same time as the Soviet Union started to sign cultural exchange agreements and establish friendship societies with the West. By 1957, the so-called friendship societies had been established in 47 countries and in time, the Soviets established relations with them. In the 1980s, SSOD entertained relations with 140 countries altogether.

The Soviet Ministry of Culture under the Soviet Council of Ministers and its subordinate organizations (the Administration of Foreign Relations, Collegium for External Cultural Relations, and the Main Leadership of Musical Establishments) took care of the practical preparation and dispatch of companies abroad and the reception of foreign artists performing in the Soviet Union. Two other state organizations, the Soviet Concert Tour Office Gastrolnoe buro, and the Soviet State Concert Agency, Goskontsert divided the responsibilities with the Ministry of Culture in controlling the foreign concert tours and organizing the international as well as all-union competitions and festivals. ${ }^{17}$ These organizations - controlled by Soviet party and government - started to cooperate with Western non-governmental organizations in the field of cultural exchanges - production of recordings, and also distributions of recordings and Soviet literature to foreign countries.

\section{Finland as a gateway for artists and artistic delegations}

In the beginning of the 1950s, despite increasing Finnish interest in the Soviet Union, it was believed in the USSR, that Finnish authorities were too oriented towards developing cultural relations with the West. ${ }^{18}$ This was despite the fact that during that time Finland belonged to those countries with which the Soviet Union had the most cultural exchanges.

The concert tour of the 240-member A. V. Aleksandrov Academic Ensemble of Song and Dance of the Red Army to Finland in January 1945, was important for the beginning of friendly relations between the Soviet Union and Finland. This was an overture to Soviet-Finnish music relations. After this, increasing numbers of classical music soloists began to tour Finland. Finland was the site of the first foreign concert tours in the West for violinist David Oistrakh, pianist Emil Gilels and pianist Sviatoslav Richter (Oistrakh's in 1949, Gilels's in 1951 and Richter's in 1960).

2013); O reorganizatsii VOKSa. Sekretariat TsK KPSS [About reorganization of VOKS. In the Secretariat of CC CP], September 5, 1957. RGANI (Russian State Archive for Contemporary History) f. 89 , per. 55 , d. $21: 1-34$.

17 See for example the materials of the Russian State Archive of Literature and Art (Rossiiskii Gosudarstvennyi Arkhiv Literatury i Iskusstva, RGALI). See also Nigel Gould-Davies, "The Logic of Soviet Cultural Diplomacy," Diplomatic History 2 (2013), 193-214; See more about the network of Western European Friendship Societies in connection with cultural relations with the Soviet Union, John Van Oudenaren, Détente in Europe. The Soviet Union and the West since 1953 (Durham and London: Duke University Press, 1991), 283-296.

18 Kinnunen 1998, 181. 
After the victories of Gilels and Oistrakh in the pre-war international competitions, they were tested in Finland before their further outreach to the West. Thus their Finnish concert tours were very important for their development as Soviet cultural diplomats. Finland became a gateway to the West for Soviet performers because Soviets trusted that Finland was in no position to help Soviet performers defect to the West or give them political asylum, at least in the early days of the Cold War period. The Soviet Union recognized Finland's desire to remain outside of superpower conflicts and to adopt a policy of neutrality. In the Agreement on Friendship, Cooperation and Mutual Assistance of 1948, Finns had specifically promised to fight against any Western attack on the USSR through their territory. The Agreement on Friendship, Cooperation and Mutual Assistance was not only an agreement of security politics but, as I will show, it also determined and outlined the policies of cultural relations and exchanges between the USSR and Finland.

In the beginning of Soviet-Finnish cultural exchange many tours were organized within the framework of the policies of Finland-Soviet Union Friendship Society. Oistrakh, Mstislav Rostropovich, a 22-year-old cellist, a professor at the Moscow Conservatory, and Gilels toured and gave concerts in Finland as part of a Soviet artistic delegation invited by the Finland-Soviet Union Friendship Society. Both tours were organized during the celebrations of "Peace, Friendship and Co-operation Month." This celebration started on the anniversary of the October Revolution and ended on Finnish Independence Day. ${ }^{19}$ The 1949 Celebrations of the October Revolution took place at the same time as the fiveyears festivities of the Finland-Soviet Union Friendship Society. Rostropovich, as other Soviet soloists in the future, was sent to overseas concert tours after winning international competitions. ${ }^{20}$ After his Finnish concerts in Helsinki and smaller cities in October of 1949 he was also awarded the coveted Stalin Prize in 1950. ${ }^{21}$

Already a Stalin Prize Laureate, Professor Gilels, with an artistic delegation of 12 other musicians, performed in at least thirteen Finnish cities during the Friendship and Co-operation Month in 1951 achieving fame in every one of them. 22 Gilels had his own concerts with the Helsinki City Philharmonic, directed by Jussi Jalas. In these concerts, he played one of the most celebrated concertos of his country and of world's classical piano repertory, Pyotr Tchaikovsky's Piano Concerto. ${ }^{23}$ In addition to Russian classics, the Soviet government and its

\footnotetext{
19 Sources (mainly newspaper archives) documenting this 1949 tour are to be found from the archives of the Finland-Soviet Union Friendship Society at the Finnish National Archives. See also Meri Herrala, "David Oistrakh and Sviatoslav Richter Stepping Through the Iron Curtain" in Ei Ihan Teorian Mukaan, ed. M. Majander, K. Rentola, (Helsinki: Työväen historian ja perinteentutkimuksen seura Yhteiskunnallinen arkistosäätiö, 2012), 244.

${ }^{20}$ Before his Finnish tour, Rostropovich had won competitions in Prague, Czechoslovakia (the first prize) and Budapest in 1947, 1949 and 1950.

21 "Mstislav Rostropovitch," Hufvudstadsbladet 29.11.1949.

22 Raivaaja 7.12.1951; Vapaa Sana 5.6.1981.

23 Uusi Päivä 12.12.1951; Vapaa Sana 4.12.1951; Helsingin Sanomat 4.12.1951
} 
governmental concert agency, Goskontsert, ordered him to perform the latest Soviet works, such as Dmitry Shostakovich's Preludes and Fugues and Sergey Prokofiev's Vision Fugitives.24 It was seen in the Soviet repertory decision of their foreign concert tours that the knowledge of traditions and cultures of the visiting and the host country was spread while strengthening mutual respect for cultures and political systems. Thus the Soviet government ordered its musicians to perform traditional Russian classics as well as official Soviet repertory but also the best works of their host country. Many times, new Soviet works had their premiere in the West in Finland after their Soviet premieres. ${ }^{25}$

Soviet violinists often performed Sibelius's Violin Concerto for Finnish audiences. The Finnish audience loved its Sibelius, but Sibelius was also performed because in the Soviet Union Jean Sibelius was equally loved and extolled (in fact, he was one of the few Finnish composers who was actually wellknown in the country). Oistrakh performed Sibelius's Violin Concerto with the Helsinki City Symphony Orchestra and Martti Similä in November 1949. Later, within the framework of the International Sibelius Violin Competition organized in Helsinki, several Soviet violinists performed Sibelius's beloved concerto as a part of the official competition program. Young violinist Victoria Mullova won a special prize from her Sibelius rendition during the 1980 Sibelius Competition. ${ }^{26}$ Many Soviet composers, violinists and other performers also had the honor of visiting Sibelius in his home, Ainola, prior to Sibelius's death in 1957.27

The so-called "Geneva Spirit" after the 1955 foreign ministers conference, considerably increased Soviet interaction with the West. The Soviets started sending more frequently their performing musicians across the Iron Curtain within the framework of the cultural exchange agreements. The secretariat of the Central Committee of the Soviet Communist Party decided to widen cultural relations with Finland on October 1, 1955, by signing the agreement on scientific, economic and technical cooperation. The strengthening of Soviet-Finnish scientific, economic and technical relations also occurred within the framework of the Finnish-Soviet Agreement of Friendship, Cooperation and Mutual Assistance.

Finland's role as a test case became more important within the context of this new openness of the "Geneva Spirit." Oistrakh's, Gilels's, and Rostropovich's concert tours to Finland helped to pave their way through the Iron Curtain. Thus in 1955, both Oistrakh and Gilels were sent to America as the first Soviet touring artists after the war. For Rostropovich, it took seven years to cross the Iron Curtain to America -in April 1956.28

\footnotetext{
24 Gilels performed these works for Finnish composer, Jean Sibelius when he visited his home Ainola in Finnish Southern town, Järvenpää, Kansan Sana 27.11.1951; Helsingin Sanomat 3.5.1963.

25 See for example violinist Mikhail Vaiman performing Shostakovich's Violin concerto after its Soviet premiere in Finland in 1956, Työkansan Sanomat 27.9.1956; Uusi Suomi 27.9.1956.

26 Uusi Suomi 6.7.1983.

27 Gilels' visit to Ainola see Totuus 21.3.1952; Vapaa Sana 27.11.1951.

28 National Archives and Record Administration of the United States (NARA), RG 59, CDF 19551959, box 121, Rostropovitch, Mistislav.
} 
Also, pianist Sviatoslav Richter's widely celebrated concerts in Finland in May 1960 served as his springboard to the West. Before his Helsinki and Turku concerts, Richter had already vigorously performed in the Eastern bloc, giving approximately 120 concerts per year. Despite the continuous offers from the representatives of the biggest Western concert agencies, the Soviet government had banned Richter from the West for a long time. This is because it was suspected by the Soviet officials that Richter would defect if he were sent to the West. 29

The question of sending Richter to the West was only resolved in February 1960, when the Central Committee Department of Culture confirmed the Committee for State Security's (KGB) decision allowing Richter to perform in the West. ${ }^{30}$ The KGB had decided that Finland was an ideal location in which to test Richter's allegiance to the Soviet Government.

Due to the risk of defection, Soviet artists were monitored by their government when they performed outside the Soviet Union. The function of so-called travel companions, secretaries, interpreters, or "gorillas," as they were secretly known among the Soviet performers, was to follow the soloists at all times. The representative of the Committee on Artistic Affairs of the USSR, A. A. Martveyev, kept an eye on Oistrakh's and Rostropovich's group as its official director in 1949. This was regarded as an especially necessary measure, when Soviet soloists visited capitalist countries. Upon their return to the Soviet Union, "gorillas" and soloists were compelled to write comprehensive reports about the activities of their group during the tour. This task was reserved for composer Yurij Milyutin, who led the delegation of thirteen Soviet performers who visited Finland in 1951. In his report from the pages of the mouthpiece of the Union of Soviet Composers "Sovetskaya Muzyka," in March 1952, Milyutin stressed the importance of cultural exchanges as a necessary measure for increasing information about each other's countries strengthening the friendship among people. ${ }^{31}$ During their tour, Milyutin always remembered to add that the art of the delegation served the cause of peace and friendship. ${ }^{32}$

In some cases, the control was not so absolute. At least some Soviet musicians were allowed to drive their own cars to Finland. This was a good way to avoid the company of "gorillas," who, of course, might have followed their musicians in their own means of transport through Vyborg and Vaalimaa border crossing points between the border of Soviet Union and Finland. Gilels and violinist Leonid Kogan were both car enthusiasts, and because of their honorariums from overseas concert tours in foreign currency, they had been able to purchase

\footnotetext{
${ }^{29}$ Minister of Culture N. A. Mikhailov to the Central Committee, 8 December 1959, Russian State Archive of Contemporary History (Rossiiskii Gosudarstvennyi Arkhiv Noveishei Istorii, RGANI), F. 5, op. 36, delo 103: 159.

30 Memorandum of the CPSU Central Committee (CC) Department of Culture, with the approval of the secretary of the CC on Richter's visit to Finland, 24 February 190, see RGANI, F. 5, op. 36, delo 103: 167.

31 See Sovetskaya Muzyka 3 (1952); Pravda, 21.3.1952.

32 Kansan Sana 8.12.1951.
} 
Western cars. Gilels owned a Mercedes Benz, and Kogan had an even bigger car, a Buick. Kogan was known for driving his car through almost all of Europe during his concert tours. ${ }^{33}$

\section{Financial conditions}

Even though the Finland-Soviet Union Friendship Society was the primary agency behind the activities of the tours of the Soviet artistic delegation of 1949 and the one of 1951, the local commercial concert office, the Fazer Concert Office Inc., headed by Elsa Salminen and Roger Lindberg, was its important organizing partner. As years passed, several other commercial organizations started to maneuver in the field of cultural relations between Finland and the USSR. Also the Finnish National Opera, organizers of commercial music festivals (for example "Sibelius Week") actively participated in the field of cultural exchanges.

Because the Soviet leadership had realized that their artistic excellence created not only political and diplomatic credibility, but also financial legitimacy for the Soviet Union, the Soviets had increasingly started to send their best performers to countries that could offer the highest concert fees, and organize the most favorable conditions for Soviet soloists and performing groups. Several archival documents show that organizations and individuals in the West successfully negotiated with the Soviet political and governmental level organizations in bringing Soviet performers to the West.

A furious competition was waged for organizing Richter's concerts tours and negotiating agreements on recordings of his performances. ${ }^{34}$ Such American impresarios as Sol Hurok, and his Hurok Artists Incorporated as well as Frederick Schang and his son from Columbia Artists Management played significant roles in negotiations with the Soviets (the Soviet State Concert Agency), organizing the concert tours of Soviet soloists. The Soviet Ministry of Culture became involved in negotiating with them during Richter's outreach to America from October to December 1960.

The Fazer Concert Office and its executive officer, Roger Lindberg, had the honor of organizing Richter's concerts in Helsinki and Turku. ${ }^{35}$ Also, the Turkubased company Allegro helped with the organization of the Turku concerts. ${ }^{36}$ Several Western record companies also competed over record deals with Richter. ${ }^{37}$ However, none of them was awarded a deal for Richter's Finnish performances.

\footnotetext{
33 Helsingin Sanomat 5.3.1963.

34 More about the longstanding struggle to allow Richter to cross the Iron Curtain, Herrala 2012, 249-251.

35 Herrala, "David Oistrakh and Sviatoslav Richter", 251. Also Richter's Carnegie Hall Recordings “Intrigues Behind Sviatoslav Richter's First Carnegie Hall Recordings in 1960." This unpublished article manuscript is at the disposal of the author.

36 Sibelius Museo document.

37 Herrala 2012, 253-254. Also Herrala article manuscript at the disposal of the author, Meri Herrala, “Intrigues behind Sviatoslav Richter's First Carnegie Hall Recordings in 1960.”
} 
Because Finland, in the 1950s and the 1960s, was the only country in which the Soviet Union normally paid the expenses of its own artists, Soviet authorities warned Finland that this could complicate the visits of Finnish artists to the Soviet Union in the future. This sounded alarming for the Finnish side because the cultural exchange between Finland and the Soviet Union was already unbalanced - considerably more artists were directed from the Soviet Union to Finland than vice versa. ${ }^{38}$ Additionally, Finns wanted a more diverse and balanced exchange than that which the Soviet cultural policy organizations, The Soviet Ministry of Culture and Goskontsert, the All-Union Society for Cultural Relations with Foreign Countries (VOKS), the Union of Soviet Societies for Friendship and Cultural Relations with Foreign Countries (SSOD), or the Soviet Friendship Society with Finland (the Soviet-Finnish Society) could organize. ${ }^{39}$ Finnish artists having difficulties transferring their ruble-based earnings back to Finland certainly backed this view against unbalanced exchanges. ${ }^{40}$

One of the reasons why considerably fewer artists visited the USSR than vice versa was that the Soviet Union also had very high quality demands for soloists and groups it accepted to perform in the Soviet Union. This was not only a problem concerning Finland and the Soviet Union but in many other cases between the USSR and other countries. It was also important for the Soviet Union that foreign performers and performing groups touring the Soviet Union needed to showcase culture based on their national traditions. ${ }^{41}$

In the end, the reasons for Soviet-Finnish cultural exchanges were more ideological and political than commercial. Thus the Soviet Union also sidelined the economic profits in favor of the need for strengthening Soviet-Finnish friendship. It was officially believed that cultural exchanges advanced the understanding between two countries and therefore were important for both Finland and Soviet Union in strengthening relations between them. This quest was confirmed by the establishment of The Soviet Friendship Society with Finland on January 13, 1958 - around the same time as the Soviet Union started to sign cultural exchange agreements and establish friendship societies with the West.

One example of the fact that financial gains were not behind the Soviet decision to send their soloists and performing groups to Finland was the case of the Borodin Quartet's concerts in Finland during the Sibelius Week in Turku in 1959. Months of negotiations and letters back and forth between Finland and the

\footnotetext{
38 Kinnunen 1998, 126.

${ }^{39}$ Ibid., 194.

40 Ibid., 122.

41 For example during the period of $1955-1972$, the number of Soviet classical music soloists to the U.S. outnumbered the quantity of American soloists sent to the Soviet Union. See both RGANI, F. 5, op. 64, delo 126: 20-24 and "Spravka ob obmenakh hudozhestvennymi kollektivami mezhdu SSSR i SShA po linii Ministerstva kultury SSSR s 1955 po 1973 g.) “in Kultura i vlast ot Stalin do Gorbacheva. Apparat TsK KPSS i Kultura 1965-1972 (Moskva: Rosspen 2009), prilozhenie 2, 1l. 1089-1092 and "Spravka ob obmene solistami mezhdu SSSR i SShA s 1955 po 1972 g.", in Kultura i vlast 1965-1972 (2009), prilozhenie 3, 1092-1097.
} 
Soviet Union were sent, before the confirmation of the decision to send the Borodin Quartet and pianist Lev Oborin to Finland, instead of the Beethoven Quartet and Dmitry Shostakovich as piano soloists - the first choice of Finnish Radio and the Fazer Concert Office. The sending of the Beethoven Quartet had been the original plan, but when it seemed that the Soviets were unwilling to send the Beethoven Quartet to Finland, Finnish Radio proposed that the Borodin Quartet, and Lev Oborin would be sent as a piano soloists instead. The honorarium of these concerts were just enough to fulfill the travel expenses of Soviet artists to Finland, but when the Central Committee Department of Culture finally asked for the confirmation of the matter from the Central Committee in April 1959, the decision was confirmed quite soon after that. The expenses of sending the Borodin Quartet to Finland with pianist Oborin would be 4,580 roubles and the income from the concerts would be 5,036 roubles. The Borodin Quartet with Oborin would play Shostakovich's Piano Quintet instead of the original plan of getting Shostakovich as a soloist. ${ }^{42}$

\section{Other Problems in Impending Soviet-Finnish Cultural Exchanges}

In order to maintain cultural exchange between Finland and the USSR in financially difficult circumstances, VOKS awarded a five-million-mark credit to the Finland-Soviet Union Friendship Society so that Finland could provide for the expenses of Soviet soloists touring the country in 1958.43 Also in practice, the Soviet donation in name of composer Dmitry Shostakovich, who had been awarded the Wihuri Foundation's Sibelius Prize (worth seven million marks), and who was persuaded by the Soviet officials to give back his grant to Finland, strengthened the financial possibilities for Finnish-Soviet convergence. ${ }^{44}$

Because in the Soviet Union cultural exchanges belonged under the jurisdiction of official foreign policy, many matters belonging to a normal operational level in Finland were state secrets in the USSR. This is why, despite the official plans for exchanges, the general fulfillment of plans was often uncertain, especially during

42 RGANI F. 5, op 36 delo 103 (Nikolai Mikhailov, Minister of Culture of the USSR to the Central Committee, April 1, 1959); RGANI F. 5, op 36 delo 103 (Spravka o peregovorakh otnoshitelno gastrolei kvarteta im. Bethovena v Finliandii, 4.3.1959 g.): 23-25, 30.

43 Ibid., 126.

44 "Suomalaisen kulttuurin juhla Helsingin yliopistossa. Wihurin kansainvälinen palkinto Dmitri Shostakovitshille ja Rolf Nevanlinnalle," Kansan Uutiset 10.10.1958; According to Ville Pernaa, the sum was 100,000 Finnish marks. This information is based on one of the interviews conducted by Pernaa, and considerably differs from information of many Finnish newspapers. According to Pernaa, KGB official Albert Akulov had announced to Shostakovich, upon his arrival to Finland, that he was not able to keep the prize money for himself. See Pernaa 2002, 100. See more about financial conditions of Finnish-Soviet cultural exchanges from Pernaa, Tehtävänä Neuvostoliitto, 8182, 100; "Matkustan mielelläni ja toivon voivani nähdä maatanne paljonkin. Iltapäivätee Shostakovitshin kanssa"; Martti Vuorenjuuri ja Leo Schulgin Leningradin pikajunassa 8.10.1958," Helsingin Sanomat 9.10.1958; "Suuri Dmitri saapui Helsinkiin, Päivän Sana 9.10.1958; Uusi Suomi 9.10.1958; "Dmitri Shostakovitsh saapui terveenä ja iloisena. Sydämellinen vastaanotto Helsingin asemalla," Kansan Uutiset 9.10.1958; "Säveltäjä Shostakovitsh saapui hakemaan palkintoaan", Maakansa 9.10.1958. 
the 1940s and 1950s. For this reason, negotiations with the Soviet Union on cultural exchanges were often conducted in the Soviet embassy in Finland or during the visits of Finnish cultural delegations to the Soviet Union. Because of the secrecy and unpredictable timing of Soviet concert tours, it was never really certain whether Soviet performers would arrive in Finland. Information about their arrival was often obtained only two days before the concert tour. The Soviet leadership would also change its mind on short notice about sending certain performers to the country. When this happened, a plausible excuse - a performer taken ill - was announced to the Finnish organizers. They of course had a hard time finding a substitute performer. 45

Especially tragicomic is a story told by violinist Gidon Kremer when Swiss concert organizers had been anxious about whether or not Kremer would perform in Swizerland. Goskontsert had not yet confirmed his concert in the country. The Goskontsert representative, next to whom Kremer had stood, had told the Swiss representative that the Soviets were not yet certain whether or not the concert would materialize. This is because Kremer had just gotten into a car accident the previous day, and the Soviets were not yet certain whether or not Kremer could perform. ${ }^{46}$ There were also cases in which Soviet soloists who had already sat down in the plane with their passports have been suddenly taken back by Soviet officials. 47 This is how the Finnish government became experienced in organizing big cultural events on very short notice.

When it came to concert tours of Finnish performers to the Soviet Union, they had the unenviable task of applying for their return visa inside the Soviet Union. Only a one-way visa was given to them for touring in the Soviet Union. ${ }^{48}$ It could be suggested that touring in a communist bloc country for a while without official permission to return back to the West must have been distressing for Western individuals and responsible for decreasing Finnish visits to the Soviet Union.

\footnotetext{
45 There are several cases of postponement or cancellation of concerts by Soviet soloists in several archival materials, memoirs and newspaper articles. See for example RGANI. Finnish daily Helsingin Sanomat reported to its readers about several occasions in which several soloists such as conductors Dmitry Kitajenko, and Yuri Temirkanov, pianist Andrei Gavrilov, cellist Rostropovich etc. had taken ill. See for example Helsingin Sanomat 24.12.1979. Of course other Western newspapers also reported about these cases (for example Der Spiegel). Rostropovich told Seppo Heikinheimo, a journalist of Finnish daily Helsingin Sanomat, that he was not always informed in a timely manner by the Soviet government that he had become "ill," which occasionally caused some awkward moments with the media, when Rostropovich was invited to foreign concert tours, see Helsingin Sanomat 5.12.1979.

${ }^{46}$ Helsingin Sanomat 24.12.1979.

${ }^{47}$ Even as late as in the 1980s, Viktoria Mullova was informed about her concert tour to Finland only two days beforehand. According to violinist Gidon Kremer, Soviet performers were often informed even one day before the concert tour whether or not they could travel, Helsingin Sanomat 24.12.1979. 48 I have no information on how often the return visas took too much time to be issued causing Finns to be detained in the Soviet Union longer than they felt comfortable.
} 


\section{0s: the high tide of Soviet-Finnish cultural exchanges}

Despite the problems, economic and cultural relations between Finland and the Soviet Union were invigorated during the period of 1955-1964. Especially in the 1960s, due to leftist cultural and scientific intelligentsia of Finland, cultural connections between the two neighbors proliferated. At the same time, the Soviet cultural policy leaders strove to widen relations with their Finnish neighbors in order to maintain leftist cultural influences in the country.

On August 26, 1960, cultural relations were codified with the agreement on cultural and educational co-operation between Finland and the Soviet Union. Several other agreements complemented this agreement. ${ }^{49}$ A new cultural exchange agreement between Finland and the Soviet Union was signed on October 4, 1963. Co-operation between Finland and the Soviet Union further expanded during the years between 1965 and 1974.

Maintaining Finnish admiration for Soviet culture remained essential in the intensifying struggle between Soviet and American culture for the hearts and minds of Western audiences. American cultural influences in the form of popular music and jazz were gradually winning over the audiences. What is more, the globalized market economy was also gradually taking over the cultural production. The system of friendship societies was increasingly superseded by the system of concert firms, record companies and impresarios seeking to capitalize intellectual property of foreign stars, as well as the rising Finnish singers and conductors. Therefore, the Soviets found it increasingly important to maintain their grip on Finnish cultural relations. This was attempted by repeatedly sending Soviet soloists and performing groups to Finland. These groups had already achieved the admiration of Finnish audiences during their previous tours in Finland.

For example, Oistrakh, Gilels, and Richter returned to Finland to perform Oistrakh, for example, in 1954 and 1958, and Richter in 1963 with Leonid Kogan. ${ }^{50}$ In 1954 and 1958 Oistrakh concerts in Finland once again preceded his tours to the United States in 1955 and 1959. Gilels loved Finland and Finnish audiences so much that he performed here almost every year. ${ }^{51}$ When Rostropovich revisited Finland in 1958, he was already a renowned soloist all over the world. ${ }^{52}$ Because of their Western successes, the USSR would continuously send these performers to the West in order to acquire important foreign currency for the country but also

\footnotetext{
49 Kinnunen 1998, 288; Pernaa 2002, 81, 110.

50 Violinist Leonid Kogan came to Finland in 1969 with his family. His wife, Emil Gilels's sister, Elizavet Gilels-Kogan was an accomplished violinist by herself and they often performed together. Before 1963, Kogan had visited Finland three times, Helsingin Sanomat 5.3.1963. Record about Oistrakh's visit in Sibelius Week in June 1954, RGANI, F 5, op. 17, delo 494, rolik 5721. See also a source of his 1958 visit, RGANI, F. 5, op. 36, delo 56, page 161.

51 According to Helsingin Sanomat, Gilels performed in Finland at least in 1963, 1965, 1970, 1976, 1977, 1978, 1979, 1983, and 1985 (his last performances before his death). I have also analyzed newspaper articles from the Sibelius Museum in Turku, Finland, for this information.

52 “Rysk cellist återvänder berömnd," Hufoudstadsbladet 5.9.1958.
} 
to maintain good relations between the Soviet Union and its cultural exchange partners in the West.

Oistrakh, Gilels and Richter, although they were the first Soviet soloists that were sent to the West, stayed true to their socialist motherland for the rest of their lives. Thus in their case the fact that the Soviet Union had tested them in the West was proven beneficial to the USSR. Oistrakh was used by his government as a cultural diplomat in the political playing field as long as he lived. ${ }^{53} \mathrm{~A}$ year before his death, Oistrakh performed in the 25th Anniversary Celebrations of the Finnish-Soviet Agreement of Friendship, Cooperation and Mutual Assistance organized by the Finland-Soviet Union Friendship Society. He performed on the podium of one of the newest cultural halls Kulttuuritalo (Cultural House) in Helsinki that became an important arena in relations between the Soviet Union and Finland. ${ }^{54}$ This was one of several performances of a political nature for Oistrakh in the history of Soviet-Finnish friendship. ${ }^{55}$ However, on this occasion, the Helsingin Sanomat reporter wished that the Finland-Soviet Union Friendship Society would bring Soviet soloists more often to Finland. 56 This means that more performances within the political level in the framework of Finnish-Soviet relations were sought in addition to occasions of a more artistic and economic nature as international competitions and festivals.

Within the process of globalization of cultural relations, and with the widening of Soviet cultural relations with foreign countries Soviet soloists became more aware of life in the West and began to compare the everyday living conditions between their motherland and the West. In the 1960s, 1970s and 1980s, increasing number of Soviet soloists started to emigrate. Soviet soloists already living in the West (as a result of defection, exile or permission from the Soviet government) frequently toured in Finland. Thus Finnish music journalists, such as Seppo Heikinheimo, had the privilege of obtaining intimate interviews from such soloists as young pianist Vladimir Ashkenazy and Rostropovich. These musicians opened their hearts to Heikinheimo about internal conflicts connected to living under the pressures of the Soviet system and the motives behind their emigration. Finland offered these soloists a safe haven, reminding them of their homeland to where returning was unthinkable or impossible. Ashkenazy feared not getting permission to exit again, ${ }^{57}$ and Rostropovich and his wife were kept in the West by the Soviet authorities.

\footnotetext{
53 Oistrakh died during his concert tour in the West in Amsterdam in 1974, the same night after performing with the Consertgebow Orchestra after suffering his second heart attack. See for example D. F. Oistrakh. Vospominaniia, Stat'i, Interv'iu, Pis'ma (Moskva: Izdatel'stvo Muzyka, 1978), 50-53; Ingeborg Stiehler, David Oistrakh. Begegnungen (Leipzig: Edition Peters 2004), 150.

54 See for example academic study by Aleksi Malmberg, 2012).

55 Helsingin Sanomat 5.4.1974; Helsingin Sanomat 7.4.1973.

56 Helsingin Sanomat 7.4.1973.

57 Ashkenazy thought that the Soviet authorities would not try to persuade him to stay in the Soviet Union, or would even keep him there as a hostage. See "Ashkenazy, Pianist, going to Moscow for 10 Days," New York Times May 11, 1963.
} 
After his emigration in 1963, Ashkenazy travelled in foreign countriesespecially in Europe and the United States - with a Soviet passport. ${ }^{58}$ He would always return to Finland to give concerts after his unofficial exile in the West. Finland had become a "substitute for Russia" to such an extent that Ashkenazy had even been searching for a summer cottage there in addition to his cottage in Greece. ${ }^{59} \mathrm{He}$ later purchased one near Savonlinna where he used to give concerts in addition to other Finnish cities. ${ }^{60}$

Ashkenazy and his Icelandic wife Thorunn (Dody) Johannsdottir, had decided to stay in London when the pianist performed in London for the first time in 1963.61 In April 1963, the Soviet embassy in London had given them permission to stay there as long as they chose. Ashkenazy would keep his Soviet passport (since he was not defecting). ${ }^{62}$ However, in 1963 the world started to understand that the Soviets saw Ashkenazy's indefinite and continuous residency in the West as virtual defection. ${ }^{63}$

For cellist Mstislav Rostropovich, Finland was an important country in the West after the Soviet Union had forced him into exile. Rostropovich had ended up on bad terms with the Soviet government because of his open defense of writer Aleksandr Solzhenitsyn and his work. ${ }^{64}$ Once again, Finnish audiences had the privilege of reading about internal political issues of the Soviet Union from an article by Seppo Heikinheimo. As Rostropovich told Heikinheimo, he was forced to move to the West because the Soviet government had prevented him from performing, and therefore also from expressing his art. This situation distressed Rostropovich to such an extent that he was finally near suicide when he applied

58 Helsingin Sanomat 1.10.1971; Helsingin Sanomat 27.1.1976. In 1976 Ashkenazy already had his Islandic passport, Helsingin Sanomat 27.1.1976; Faubion Bowers, “Russia's Ashkenazy: He Can't (Won't?) Go Home Again," New York Times 23.1.1972.

59 Helsingin Sanomat 1.10.1971. See also Helsingin Sanomat 5.8.1974 about Ashkenazy's summer cottage in Greece and Finland around the Savonlinna area.

${ }^{60}$ Helsingin Sanomat 27.1.1976.

${ }^{61}$ In 1962 Ashkenazy had asked the Soviet Ministry of Culture Yeketarina Furtseva for permission to visit his wife's parents in London after his eight-week tour in the United States. The Soviet minister of Culture was willing to give Ashkenazy and his wife permission to visit London, but needed confirmation from the Central Committee Department of Culture. The Central Committee obviously supported this decision because Ashkenazy stayed in London after his concert tour there in 1963. See RGANI, F. 5, op. 36, delo 143, rolik 5852.

62 Faubion Bowers, "Russia's Ashkenazy: He Can't (Won't?) Go Home Again," New York Times 23.1.1972; "Ashkenazy, Pianist, going to Moscow for 10 Days," New York Times 11.5.1963; Gwen Morgan, "Soviet Pianist is Afraid to Return Home: Ashkenazy Fears He Will Be Kept There," Chigago Tribune August 22, 1969; Hurok Attraction Here: Ashkenazy, Soviet Jew, New York Times January 27, 1972

63 See for example NARA, RG 59, Box 4127, Kohler from Moscow to Secretary of State April 17, 1963. 64 Rostropovich's trouble with the government was severed because he had offered the writer premise in the annex of his datcha outside Moscow, Helsingin Sanomat 5.12.1979. Also Solzhenitsyn was also forced into exile and had went into seclusion in his house in Vermont, United States. According to Rostropovich's explanation, Solzhenitsyn had seaken a possibility to compensate his lack of writing during his time in Soviet Gulag, Helsingin Sanomat 5.12.1979. 
for a permit to move overseas. ${ }^{65}$ General Secretary Leonid Brezhnev through the Soviet Minister of Culture, Ekaterina Furtseva, had given Rostropovich permission to leave the country for a period of two years. 66

Rostropovich and his wife, soprano Galina Vishnevskaya, were deprived of their Soviet citizenships by a decision of the Presidium of the Supreme Soviet of the USSR on March 14, 1978, because of their anti-Soviet activities in the West. ${ }^{67}$ Obviously, their understanding of freedom of individuals in the Soviet system had collided with the one predominant in the Soviet Union. Many Soviet soloists were able to prolong their overseas visas for indefinite periods of time. This was also true of Rostropovich and Vishnevskaya, which strongly implied that they had no intention of returning to the Soviet Union - their homeland. This type of behavior was seen by the Soviet Central Committee as persuading fellow intellectuals, artists, and musicians to emigrate to the West. ${ }^{68}$

Despite the increasing "traffic" across the Iron Curtain, new Soviet soloists were introduced in Finland, for example when they came to take part in the international Sibelius Violin Competition, ${ }^{69}$ music festivals, Helsingin Juhlaviikot, Sibelius week in Turku, Jyväskylä Summer, Jyväskylän Kulttuuripäivät (Jyväskylä Cultural days), and others, and to give master classes to Finnish and international musicians.

One of the young Soviet soloists who got wind in the sails of her international career in Finland was Viktoria Mullova, a 21-year-old violinist, who shared the first prize of the Sibelius Competition with her countryman Sergey Stadler. Mullova's and her accompanist, conductor Vakhtan Jordania's 1983 defection to the West via Finland literally showed that Finland would serve as a stepping stone to the West. ${ }^{70}$ According to Mullova, the reasons for their defection were artistic not political. Mullova as many other soloists before and after her, felt that her government did not give her enough artistic freedom - insufficient opportunities to perform, record, and no satisfactory locations for practicing.

\footnotetext{
65 Helsingin Sanomat 5.12.1979.

66 Rostropovich had told American ambassador in Moscow of the decision on April 22. Rostropovich would emigrate along with his wife, and his two daughters. See Central Foreign Policy Files at the NARA electronic database, Subject: American Embassy Moscow to Secretary of State Washington D.C. April 1974. Rostropovich had also received backing for his wishes to spend some time in Europe and the United States from Senator Edward Kennedy after American conductor, and Rostropovich's friend Leonard Bernstein had pleaded Senator Kennedy on the matter.

${ }^{67}$ Helsingin Sanomat 5.12.1979.

68 "Zapiska Iu. V. Andropova, A. A. Gromyko i M. V. Zimianina TsK KPSS s predlozheniem o lishenii M. L. Rostropovicha i G. P. Vishnevskoi Sovetskogo grazhdanstva, 10 marta 1978 g.," in Muzyka vmesto sumbura. Kompozitory i muzykanty v strane sovetov 1917-1991. Dokumenty, 16 marta 1978 g., ed., L. Maksimenkov (Moskva: Rossiia XX Vek 2013), Razdel VIII, No. 495: 665-667. The approval of this proposal by the Presidium of the Supreme Soviet of the Soviet Union from page 667.

${ }^{69}$ For example Oleg Kagan had won his second international competition in Finland when he had been awarded the first prize in the Sibelius Violin Competition in 1963, Helsingin Sanomat, 26.5.1968. 70 Åby Underrättelser 6.7.1983.
} 
What is more, Goskontsert often changed her repertory and cancelled her concerts on short notice. Even after winning the Tchaikovsky Competition Mullova had not been given enough opportunities to perform. ${ }^{71}$

\section{Conclusions}

Even though there has been understanding in the previous literature, that cultural relations between Finland and the Soviet Union were secondary to scientific and industrial relations, cultural interaction was an important means for building understanding between neighbors after the Second World War. ${ }^{72}$ Music offered a common language in inter-cultural communication despite the systemic and ideological differences between the countries.

This study has shown that according to "characteristics" of Abernethy's theory, the dominant-subordinate relationship is relevant in connection with Soviet-Finnish cultural exchange. According to his second characteristic "the consequences of the interaction between the dominant and subordinate state are more important to the subordinate states," 73 Finland, as a subordinate cultural exchange partner had more advantages from the music exchanges for two reasons. Firstly, Soviet concert tours to Finland were more frequent and more numerous in terms of visitors than vice versa. Secondly, financial support for cultural relations was directed from the dominant partner to the subordinate.

Because of Finnish tendency to adopt Realpolitik in its relations with the Soviet Union, the interaction was certainly "more important for the domestic and foreign policies of the subordinate state than those of the dominant state," as Abernethy's theory suggests. ${ }^{74}$ It was more relevant for Finland to maintain its friendly relations towards the Soviet Union than for the USSR to do so with Finland. There were certainly times in Finnish-Soviet relations when the Soviet Union tended to dictate Finnish internal policies, as in the case of the so-called "Note Crisis" in October and November of 1961, during which the Soviets strove to push Finns to elect the most suitable candidate for the USSR in the Finnish presidential elections. However, it does not seem that this crisis influenced the cultural policies in any way. Basically it is also true that "the dominant state had considerably more mutually acknowledged and valued power resources than the other." If the term "power resources" can be related to the "soft power" the USSR possessed, it can be stated that the Soviet Union perhaps had more "soft power" than Finland, at least when understood using the indicators such as traditions, and also quality of composers and musicians. The Russian musical tradition had a longer and deeper history in the best European and Eastern traditions than did the Finnish musical culture. Despite Finland's national asset in musical culture,

71 Uusi Suomi 6.7.1983; Uusi Suomi 10.7.1983; Hufoudstadsbladet 6.7.1983; Jyrki Koulumies, Moskova, Mullova ja minä (Helsinki: Otava 2008).

72 See for example Pernaa 2002, 84.

73 Aappo Kähönen, The Soviet Union, Finland and the Cold War. The Finnish Card in Soviet Foreign Policy, 1956-1959 (Helsinki: Suomalaisen Kirjallisuuden Seura 2006), 25-26.

74 Ibid. 
the most famous Finnish composer in the world, Jean Sibelius, and Soviet top musicians and composers outnumbered those of Finland. Other categories are more difficult to analyze.

To some extent, music could be considered a tool of "soft power" when it comes to its usage as a "tool" influencing the bilateral relations during the times when bilateral diplomatic relations were deteriorated or in a stalemate. This means that policies of music and cultural exchanges could remain functional behind the scenes in a more private setting when more traditional diplomatic channels of interaction were limited, or in some cases, inappropriate or impossible. Of course this theory using "soft power" as a strategic tool between two countries seems to be more appropriate when it comes to relations between superpowers, than to the relations between the USSR and Finland. Compared to the relations of the United States and the Soviet Union, there were no such military conflicts as, for example, the Cuban Missile Crisis in 1962, during which "soft power" could have stayed functional in the background when everything else was stalled. In Finnish-Soviet case "soft power" was mainly used to integrate Finland into the Soviet "cultural imperium" in the framework of the system of friendship societies. In Finnish-Soviet relations, music was used in maintaining mutual peaceful relations between the cultural exchange partners. Because of the need to exercise moderation in the relations towards the Soviet Union, culture in general as "soft power" could not be used either for propaganda purposes during the times when Finnish-Soviet relations were deteriorated, or to offset a Soviet threat, or Soviet interference in Finnish internal policies. By comparison, in relations between the superpowers, political propaganda, in the form of political cartoons was often used "tool" during the times when military intervention would have been almost suicidal.

Finnish-Soviet cultural relations were a unique phenomenon before the signing of cultural exchange agreements and the establishment of friendship associations between the Soviet Union and the western countries from the end of 1950s onwards. As I have shown, Finland had served as a test case for Soviet musicians, artists and performers, who had won international competitions and thus were already "tested" in the West before the Second World War. Now during the Cold War's changed international situation, their allegiance was once again tested in Finland before their outreach to the wider arenas in the West - including America.

When the time progressed emigration and defections of Soviet soloists to the West showed that the Soviet power was hardly so strong anymore, even towards its own citizens..$^{75}$ The political and economic collapse of the Soviet Union was

\footnotetext{
75 Several musicians and ballet dancers had defected from the Soviet Union and pleaded asylum during their concert tours in the West. According to Helsingin Sanomat, half of the leading Soviet musicians were already living overseas during the times of Mullova's defection in the 1980s. Particular attention has been given to defections of chief conductor of the Moscow Philharmonic Orchestra, Kiril Kondrashin, Dmitry Shostakovich's son Maksim Shostakovich, Rostropovich and violinist Gidon Kremer," Helsingin Sanomat 5.7.1981. Maksim Shostakovich had remained in the
} 
exacerbated by increasing defections, which further diminished its cultural influence on the West.

Artists and musicians were voices for systemic and humanitarian grievances about life in totalitarian regimes. This information was elucidated for Western audiences with the help of grass-root interactions, for example during interviews with foreign, often Finnish journalists. With the increasing traffic to the West by Soviet citizens and the resulting changes in information "infiltrating" to Finland - also because of Glasnost and Perestroika - the style of information from the East became associated with political opposition.

The relations of Finland and the Soviet Union were a continuous area of concern and in a state of flux. What remained the same was the ritualistic repetition of the rhetoric of Soviet-Finnish friendship that had become one of the central elements of the so-called "Finlandization." With the collapse of the Soviet system, and decreasing economic relations between Finland and the Soviet Union, new means of friendship and interaction became increasingly important. Again the economic profits needed to be sidelined in favor of the need for strengthening Soviet-Finnish friendship.

Even though the impact of Soviet cultural influence on foreign countries is hard to measure when it comes to abstract nature of music, I can conclude that music relations played a considerable role in Finnish-Soviet relations. Soviet musical outreach to Finland helped to strengthen the positive images of Finland's Eastern neighbor, its system, culture and people. Although in the 1970s, tourism between Finland and Soviet Union widened transnational interchange across the blocs and helped to open the eyes of foreign visitors to the USSR, the concert tours of Soviet soloists and performing groups across the Iron Curtain showcased the most prominent side of the Soviet system - its culture. In the context of cultural exchange, Western artistic visitors sent to the Soviet Union brought some ideas for their Soviet audience of world beyond the Curtain. In the process, the Soviets themselves needed to adapt to the system of Western consumerism affecting also the system of cultural exchange and the relations between its Western cultural exchange partners, including Finland. Also the cultural exchange between Finland and the Soviet Union was gradually transformed under the system of concert agencies and record companies as it had happened in

West with his son Dmitry in 1981 while he had been touring in Western Germany with the Moscow Radio Orchestra. With his decision he was protesting the treatment of his father, Dmitry Shostakovich. Violinist Gidon Kremer renounced the citizenship of the Soviet Union in 1980, Helsingin Sanomat 5.7.1981 (See also Helsingin Sanomat 30.11.1977 reporting that Kremer wants to stay eight years in the West, as Rostropovich had done previously). Kondrashin stayed in the West in 1978, Helsingin Sanomat 24.12. 1979. Also according to Helsingin Sanomat in 1979, artists that were planning to emigrate from the Soviet Union were the following - conductors Andris Nelsons, Kiril Kondrashin and Rudolf Barshai, pianists Elisabeth Leonskaya and Bella Davidovich (emigrated in 1977 according to Helsingin Sanomat 30.8.1979), the winners of the Tchaikovsky Competition pianist Vladimir Ashkenazy, Lithuanian cellist David Geringas and Boris Pergamentchicov and dancers Mikhail Baryshnikov ja Aleksandr Godunov. Also conductor Neeme Järvi and composer Arvo Pärt considered emigration, which they later did, Helsingin Sanomat 5.12.1979. 
the West in the 1950s, when the first Soviet soloists and companies ventured into the West.

Despite the problems of researching the "soft power" diplomacy in SovietFinnish music relations, and the area of research being in such a state of infancy, the importance of the study of cultural exchanges in the relations between the states is increasingly vital - especially in the current re-emerging Cold-War-style conflict between the West and Russia. In the current situation of world politics, cultural and "soft power" diplomacy will once again become the one arena in which understanding with the Russians could be maintained if relations in other arenas remain in a stalemate.

\section{References:}

\section{Archives}

Memorandum of the CPSU Central Committee (CC) Department of Culture, with the approval of the secretary of the CC on Richter's visit to Finland, 24 February 190, see RGANI, F. 5, op. 36, delo 103: 167.

Minister of Culture N. A. Mikhailov to the Central Committee, 8 December 1959, Russian State Archive of Contemporary History (Rossiiskii Gosudarstvennyi Arkhiv Noveishei Istorii, RGANI), F. 5, op. 36, delo 103: 159.

National Archives and Record Administration of the United States (NARA), RG 59, CDF 1955-1959, box 121, Rostropovitch, Mistislav.

Nikolai Mikhailov, Minister of Culture of the USSR to the Central Committee, April 1, 1959, RGANI F. 5, op 36 delo 103.

O reorganizatsii VOKSa. Sekretariat TsK KPSS [About reorganization of VOKS. In the Secretariat of CC CP], September 5, 1957. RGANI f. 89, per. 55, d. 21: 1-34.

Record about Oistrakh's visit in Sibelius Week in June 1954, RGANI, F 5, op. 17, delo 494, rolik 5721.

\section{Periodics}

****, "Ashkenazy, Pianist, going to Moscow for 10 Days," New York Times May 11, 1963.

****, "Mstislav Rostropovitch," Hufoudstadsbladet 29.11.1949.

Bowers, Faubion, “Russia's Ashkenazy: He Can't (Won't?) Go Home Again," New York Times 23.1.1972.

Morgan, Gwen, "Soviet Pianist is Afraid to Return Home: Ashkenazy Fears He Will Be Kept There," Chigago Tribune August 22, 1969.

Åby Underrättelser 6.7.1983.

Helsingin Sanomat 4.12.1951.

Helsingin Sanomat 3.5.1963.

Hufoudstadsbladet 6.7.1983.

Kansan Sana 27.11.1951.

Maakansa 9.10.1958.

Raivaaja 7.12.1951.

Totuus 21.3.1952.

Työkansan Sanomat 27.9.1956. 
50 | Revista Română de Studii Baltice și Nordice / The Romanian Journal for Baltic and Nordic Studies 6 (2)

Vapaa Sana 4.12.1951.

Vapaa Sana 27.11.1951.

Vapaa Sana 5.6.1981.

Uusi Päivä 12.12.1951.

Uusi Suomi 27.9.1956.

Uusi Suomi 6.7.1983.

\section{Secondary sources}

**** , "Spravka ob obmene solistami mezhdu SSSR i SShA s 1955 po 1972 g." , in Kultura $i$ vlast 1965-1972 (2009), prilozhenie 3, 1092-1097.

****, "Zapiska Iu. V. Andropova, A. A. Gromyko i M. V. Zimianina TsK KPSS s predlozheniem o lishenii M. L. Rostropovicha i G. P. Vishnevskoi Sovetskogo grazhdanstva, 10 marta 1978 g.," in Muzyka vmesto sumbura. Kompozitory i muzykanty v strane sovetov 1917-1991. Dokumenty, 16 marta 1978 g., ed., L. Maksimenkov (Moskva: Rossiia XX Vek 2013), Razdel VIII, No. 495: 665-667.

Abernethy, David B., "Dominant-Subordinate Relationships," Jan F. Triska (ed.) Dominant Power and Subordinate States (Durham 1986).

Autio-Sarasmo, Sari, Miklóssy, Katalin and Humphreys, Brendan (Ed.), Winter Kept Us Warm: Cold War Interactions Reconsidered (Aleksanteri Cold War Series 1/2010).

Bolokitina T. V., et al., Moskva i vostochnaya Evropa. Stanovlenie politicheskikh rezhimov Sovetskogo tipa 1949-1953. Ocherki istorii (Moskva: Rosspen, 2002).

Clavin, Patricia, "Defining Transnationalism," Contemporary European History, 144 (2005), 421-439.

David-Fox, Michael, "Transnational History and the East-West Divide" in Peteri, György, Imagining the West in Eastern Europe and the Soviet Union (University of Pittsburg Press 2010).

Gould-Davies, Nigel, “The Logic of Soviet Cultural Diplomacy,” Diplomatic History 2 (2013), 193-214.

Herrala, Meri, The Struggle for Control of Soviet Music From 1932 to 1948: Socialist Realism vs. Western Formalism (The Edwin Mellen Press: Lewinston, Queenston, Lampeter 2012).

Herrala, Meri, "David Oistrakh and Sviatoslav Richter Stepping Through the Iron Curtain" in Ei Ihan Teorian Mukaan, eds. M. Majander, K. Rentola, (Helsinki: Työväen historian ja perinteentutkimuksen seura Yhteiskunnallinen arkistosäätiö, 2012).

Kähönen, Aappo, The Soviet Union, Finland and the Cold War. The Finnish Card in Soviet Foreign Policy, 1956-1959 (Helsinki: Suomalaisen Kirjallisuuden Seura, 2006).

Keohane ,Robert, and Nye, Joseph S. Jr. (Eds.), Transnational relations and world politics (Cambridge MA: Harward University Press, 1971).

Kinnunen, Kaisa, Suomi-Neuvostoliitto-Seuran Historia 1944-1974 (The History of Finland-Soviet Union Friendship Society 1944-1974) (Helsinki: Suomi-Venäjäseura, 1998).

Koulumies, Jyrki, Moskova, Mullova ja minä (Helsinki: Otava 2008).

Mikkonen, Simo, “'Winning Hearts and Minds?' Soviet Music in the Cold War Struggle against the West" in Twentieth Century Music and Politics, ed. P. Fairclough (Farnham: Ashgate, 2013).

Norman Naimark and Leonid Gibianskii (ed.), The Establishment of Communist Regimes in Eastern Europe 1944-1949 (USA: Westview Press, 1997). 
Nye, Joseph S., Jr., Soft Power. The Means to Succeed in World Politics (New York: Public Affairs, 1986).

Nye, Joseph S., Jr., "Public Diplomacy and Soft Power", The Annals of the American Academy of Political and Social Science 616: 94 March 2008, pp. 94-109.

Oistrakh., D. F., Vospominaniia, Stat'i, Interv'iu, Pis'ma (Moskva: Izdatel'stvo Muzyka, 1978), 50-53.

Pernaa, Ville, Tehtäzänä Neuvostoliitto. Opetusministeriön Neuvostoliittoinstituutin roolit suomalaisessa politiikassa 1944-1992 (Mission the Soviet Union.( The Roles of the Soviet-Union Institute of the Finnish Ministry of Education in Finnish Politics 1944-1992) (Keuruu: Otava, 2002).

Vihavainen,Timo, Kansakunta rähmällään. Suomettumisen lyhyt historia (Helsinki: Kustannusosakeyhtiö Otava, 1991).

Stiehler, Ingeborg, David Oistrakh. Begegnungen (Leipzig: Edition Peters 2004).

Turtiainen, Olli, Täältä tullaan Venäjä! Rock Suomen ja Neuvostoliiton Kulttuurisuhteissa (Here we come Russia! Rock Music in Finnish-Soviet Cultural Relations) (Turun Yliopisto: Politiikan tutkimuksen laitos, poliittinen historia, 2012). 